\title{
Beyond pure public and pure private management models: Partial privatization in the European Airport Industry.
}

\author{
Running title: Partial privatization in the European Airport Industry
}

Daniel Albalate, Germà Bel and Xavier Fageda

International Public Management Journal

17 (3), pp. 308-327, 2014

Daniel Albalate (albalate@ub.edu)

Germà Bel, Universitat de Barcelona (gbel@ub.edu)

Xavier Fageda (xfageda@ub.edu)

\begin{abstract}
The use of private funding and management enjoys an increasing trend in airports. The literature has not paid enough attention to the mixed management models in this industry, although many European airports take the form of mixed public-private companies, where ownership is shared between public and private sectors. We examine the determinants of the degree of private participation in the European airport sector. Drawing on a sample of the 100 largest European airports we estimate a multivariate equation in order to determine the role of airport characteristics, fiscal variables and political factors on the extent of private involvement. Our results confirm the alignment between public and private interests in partially privatized airports. Fiscal constraints and market attractiveness promote private participation. Integrated governance models and the share of network carriers prevent the presence of private ownership, while the degree of private participation appears to be pragmatic rather than ideological.
\end{abstract}

Keywords: Partial Privatization, Mixed Public-Private Companies, Airports. 


\section{INTRODUCTION}

The standard framework of analysis on public services delivery choices has focused on the choice between pure public production and pure private production, and a large amount of research, theoretical as well as empirical, has analyzed why governments choose to privatize public services or, instead, stick with public delivery [Bel and Fageda $(2007,2009)$ offer recent and wide reviews of this literature]. However, a sharp public - private contraposition does not take into account that organizational boundaries are not so clearly defined, and instead we can think of a public-private continuum (Perry and Rainey, 1988; Stiglitz, 1989). Furthermore, Warner and Hebdon (2001) emphasize that privatization is not the sole available option for the reform of local services, and Hefetz and Warner (2007) argue that analysis must move beyond the either/or dichotomy of public versus private production. Increasing attention has been paid to the fact that local government contracting is a complex management process, ${ }^{1}$ which combines transactions costs, managerial concerns, and social choice issues, and this has triggered interest in analyzing reforms other than strict privatization and contracting out.

One stream of research has paid attention to mixed delivery modes in the US (Stein, 1990, Miranda and Lerner 1995), where mixed delivery implies that a government divides her jurisdiction in several service districts, and pure public delivery

\footnotetext{
${ }^{1}$ Local services management offers an appropriate background for the analysis of airports economics and management. Local/metropolitan responsibility for airports is by far the most frequent model in the large OECD countries: the USA, Canada, France -besides Paris-, Italy, UK -besides BAA-, Germany together with state governments-, etc. (see Bel and Fageda, 2007, for a review and discussion of management models in the OECD countries). And more fundamentally, airports are single facilities (as opposite to surface transportation, usually characterized by networks), so they have economic characteristics similar to those of local/metropolitan public services.
} 
is used in one or more districts while pure private production is used in other district(s) within the same jurisdiction (Warner and Bel, 2008). Warner and Hefetz (2008) show significant growth in mixed delivery modes in the US since 1997, an issue further analyzed in Hefetz and Warner (2012). ${ }^{2}$

Another stream of research has been devoted to analyze why governments engage in cooperation to provide public services. This literature has developed especially for the US, where intermunicipal cooperation frequently takes the form of intermunicipal agreements through which two municipalities make a contract assigning responsibility for the service to just one of the municipalities (Holzer and Fry, 2011). As such, the system operated might be seen as intermunicipal contracting. However, other types of intermunicipal cooperation exist, such as horizontal production arrangements with other governments (see Feiock and Scholz, 2010). More generally, an interesting and fertile research agenda has been developed, based on the institutional collective action (ICA) framework, which extends theories of collective action among individuals to institutionally defined composite actors such as local government units (Feiock 2007; Feiock and Scholz 2010).

Factors influencing intermunicipal cooperation have been empirically studied in Warner and Hefetz (2002), who find that smaller cities more likely to cooperate with the larger local governments to gain economies of scale. Fiscal reasons appear to be related to the decision to cooperate, and a weaker tendency to cooperation is found for

\footnotetext{
${ }^{2}$ Empirical evidence on the effects of mixed delivery in the USA is scarce. A recent work by Davis (2012) compares different types of delivery arrangements in three cities, and finds that mixed publicprivate in Indianapolis' delivery is more fiscally efficient and environmentally effective than single monopolistic provision in Denver, and also than atomized provision by private market in Colorado Springs.
} 
communities enjoying better financial conditions [be these budget per capita (Wood, 2006), total city tax revenues (Carr, LeRoux and Shrestha, 2009), tax revenues per capita (Krueger and Bernick, 2010), or own source revenue (Kwon and Feiock, 2010)]. ${ }^{3}$ LeRoux and Carr (2007) and Leroux, Brandenburger and Pandey (2010) find that other city and regional characteristics different from fiscal conditions might be influential, and social networks might be as well. Carr, LeRoux and Shrestha (2009) find cooperation negatively related to population. Shrestha and Feiock (2011) find that interlocal cooperation is shaped by the nature and the degree of transaction risks as well as by reciprocal exchange relationships. Interestingly, Bickers, Post and Stein (2010) find inter-municipal cooperation is used as a mean to promote careers of local office holders. And, in a more recent study, Hefetz and Warner (2012) emphasize the role cooperation can play in services when competition is low.

In this paper we examine yet another strategy to go beyond the dilemma between pure delivery forms (public or private): we analyze the motivations that influence partial privatization of public services by means of mixed public-private companies (Backx, Carney and Gedajlovic, 2002). With our paper we contribute to the literature by analyzing the determinants of the degree of private participation in the European airport sector. Hence, our focus is twofold: On one hand, we focus on the choice of mixed public-private companies instead of pure management models. On the other, we focus on the degree of private participation taking into account the percentage of private ownership of the firm.

We draw on a sample including the 100 largest airports in Europe, which are characterized by a diverse involvement of private firms in their management, in order to estimate a multivariate equation using a generalized linear model with fractional

\footnotetext{
${ }^{3}$ In this regard, see also Agranoff and McGuire (2003) and Sonenblum, Kirlin and Ries (1977).
} 
response variables. The analysis considers as explanatory variables several airport characteristics (amount and type of traffic, competition from nearby airports, airline's attributes) along with fiscal and political factors taking into account that both private and public partners share interests in the association through mixed public-private companies governance models.

With this empirical exercise we find that not only privatization of airports is a pragmatic choice of governments in Europe, but also it is the degree of private ownership. In this regard, our results indicate that private participation increases where public and private interests are compatible in terms of fiscal government relief (for the public sponsor) and market attractiveness (for the private partner). Furthermore, we find evidence that specific characteristics of airports like size, congestion, competition and type of dominant airlines influence on the involvement of private partners in these facilities through the use of mixed or fully privatized firms. These characteristics affect the expectations of private investors (current traffic, competition from other airports or the congestion level) or limit the interest of governments in losing their control (the percentage of network carriers that make the airport a strategic infrastructure). Finally, this article reveals the role played by governance models in terms of individual versus integrated airport management systems as determinant of private involvement, supporting recent empirical results regarding the degree of privatization in other sectors that show that single facilities are more prone to receive higher private participation than network infrastructure (Albalate, Bel and Geddes, 2011).

Beyond the results of the role of all these characteristics leading to a larger or smaller degree of privatization we also show the importance of considering the British experience as a singularity in any study on airport privatization. As it is shown, it should be taken into account its different and deeper approach to privatization than in 
continental Europe. For this reason we claim that the British experience should be specifically treated in any empirical analysis on the European airport industry.

\section{LITERATURE REVIEW: MIXED PUBLIC-PRIVATE COMPANIES AND PRIVATE PARTICIPATION}

Mixed public-private companies are organizational forms that escape the pure public/pure private dichotomy. Their ownership is divided between the government and the private sector, and they operate exclusively under private commercial law (Warner and Bel, 2008). Mixed public-private companies differ from contracts to private firms in several relevant aspects. First, and most important, governments can exert control through property rights over the mixed public-private companies, in addition to the control that can be exerted with regulatory tools. The government retains a voice in deciding the objectives to be pursued by the firm, even if these firms are managed independently of government. Therefore, managers of mixed public-private companies under effective control of government are expected to give more weight to the objectives of government and give less weight to profit maximization (Matsumura 1998; Matsumura and Kanda 2005).

Furthermore, government participation on the governing boards of the mixed publicprivate companies helps to reduce the problems resulting from long-term incomplete contracts, thus reducing problems derived from transaction costs, which can be very important in contracting (Brown and Potoski, 2003a, 2003b, 2005). Schmitz (2000) shows that partial privatization may result in an optimal combination of incentives for reducing costs and improving quality in comparison to pure production forms (either public or private). 
Mixed public-private companies are used in several European countries. They play a significant role in the delivery of local services in Spain The private partners tend to be large firms with an established reputation for delivery of the particular local service. The government retains some degree of control in the firm, while day-to-day operations are usually conducted by the private partner (Bel 2006, Warner and Bel 2008).. This allows less costly monitoring, thus reducing transaction costs. In many cases, the government holds a majority of the shares.

Mixed public-private companies in Italy are organizationally similar to those existing in Spain, but other types of mixed organizational forms mixed enterprises are not. For instance, in Italy Bognetti and Robotti (2007) include among mixed enterprises multi-government firms,, where there are several owners and all of them are public entities. Such multi-government enterprises represent $13 \%$ of public utilities in Italy. ${ }^{4}$ This type of multi-government firm is not a partial privatisation, and is, therefore, outside our main object of study. It is important to recall that mixed public-private arrangements in the US usually have both pure private firms and pure public units delivering the service within one jurisdiction. Hence, it is not a form of partial privatization comparable to the partially privatized firms we find in Europe.

The empirical literature on partial privatization of firms providing public services is extremely scant. As far as we know, there is only one work that analyzes the factors explaining the choice of mixed public-private companies for service delivery -instead of pure public or pure private forms-, that by Bel and Fageda (2010) for local services such as solid waste and service. Our paper goes beyond that contribution because we

\footnotetext{
${ }^{4}$ Bognetti and Robotti (2003) analyze how the 2002 Financial Law promoted the using of market mechanisms in local services in Italy, including different types of public-private mixed firms.
} 
analyze not only the choice of mixed public-private companies in the airport industry, but also the degree of private participation in those mixed public-private companies.

As far as we know, the extent of private participation in mixed public-private companies has only been explored considering the choice on the contractual design of contracts in Albalate, Bel and Geddes (2011 and 2012). In these works the authors have studied the determinants of the contractual choice across different economic sectors as a proxy of private participation in the United States. On one hand, Albalate, Bel and Geddes (2011) show that private participation is greater in single infrastructure, while private collaboration has been more limited in the case of network infrastructure. Transaction costs and governance complexity might be behind this result. On the other, Albalate, Bel and Geddes (2012) just focused on the US water industry to find that differences between public and private salaries, together with the attractiveness of the potential market are two of the main factors leading to larger private involvements in a project.

\section{PARTIAL PRIVATIZATION AND MIXED AIRPORT COMPANIES IN}

\section{EUROPE}

The use of private funding and management enjoys an increasing trend in the airport sector worldwide. The use of arrangements as public-private companies may include a wide variety of contract types, institutional organizations and degrees of private involvement. However, the literature on privatization and contracting out has not paid enough attention to the mixed management models existing in the airport industry. On one hand, many European airports take the form of mixed public-private companies, partly owned by public sector and partly owned by the private sector, which implies collaboration beyond the pure public and pure private management models. This 
alternative allows complementing the public and private interests in the management of strategic infrastructure. Being this said, it is not only the presence of private ownership in the firm, but the control of the ownership (majority) the key factor determining the degree of private management of the airport.

Private participation in public-private companies also implies the transfer of risks to the private collaborator, what makes necessary an attractive business opportunity or enough State guarantees for a private partner in order to consider its participation in an infrastructure project. In transportation projects construction and demand risks are two of the largest risks faced by any operator (Engel et al, forthcoming a; Estache, 2006), and financial results of such collaboration are definitely affected by cost and demand divergences from predictions to reality (Engel et al, forthcoming b).

The term partial privatization intrinsically implies the agreement between a public sponsor and at least a private partner. Therefore, both expect to benefit from the partnership, complementing the public and private interests in the management of strategic infrastructure. On the side of the public sponsor, partial privatization provides funding for necessary infrastructure easing fiscal budget constraints, avoiding tax increases and expenditure cuts in other government activities. Also, it allows taking advantage of private incentives and specialized expertise to design, finance, build and operation activities so as to gain technical efficiency. On the side of the private partner, it seeks business opportunities in attractive markets where risks might be controlled under a safe regulatory framework given the association with the public sponsor.

In the European airport sector contractual arrangements have usually taken the form of concessions or BOT-contracts, together with asset sales. Management contracts or joint development agreements are rarely used to promote the collaboration with the private sector. As a result, it seems that private partners are incorporated in the airport 
sector through the use of contracts requiring larger extents of private participation and risk transfers. Most of this private participation is required for the upgrading of Brownfield projects or for the building of new Greenfield projects, which demand large sums of investments.

On the other hand, mixed public-private companies- the focus of our analysis - has a common organization form based on the mixed ownership in which private and public partners share the property of the firm running the Airport, even if this is organized under a concession contract. The private extent of private participation, therefore, might be measured as the percentage of the stake in private hands, what allows overcoming the dichotomy between pure public and pure private management models by including partial privatization in the analysis with mixed public-private companies.

Indeed, ownership and management of airports in Europe had been, traditionally, in the hands of the government concerned, being this the national government or regional and local governments. However, since privatization of BAA (formerly British Airport Authority) in 1987 several companies that manage airports in Europe have majority private sector participation.

Private sector participation will likely increase in coming years following the trend experienced recently. Several forces are still boosting governance reforms in the sector, such the pressure exerted on airport activity by airlines, which operate in a highly competitive environment - and therefore demand low prices and sufficient capacity to execute most of their operations-. On their side, governments often need to finance major investments in strategic airports in the current context of severe budgetary constraints and high opportunity costs. Also, privatization has triggered the emergence of 'airport cities' (Freestone and Baker, 2010), thus intensifying development around airports. 
The empirical evidence regarding the effects of privatization on economic efficiency is scarce and inconclusive (Parker, 1999; Oum et al., 2006, 2008; Muller et al., 2008; Marques and Barros, 2010).Parker finds no significant differences in terms of efficiency for BAA airports before and after privatization. Oum et al. $(2006,2008)$ use a large sample of airports around the world and show that both airports wholly or partly controlled by private investors, by public firms, or by autonomous or independent authorities are more efficient than the airports controlled by multiple agents (partially privatized joint ventures, government-controlled companies from different territorial levels) or controlled by companies with multiple objectives (port authorities in the U.S.).

Furthermore, Muller et al. (2008) analyzed the relative efficiency of the airports in the UK and Germany, considering that the first country in private ownership is more widespread. From their results, it follows that the differences between airports in both countries can be explained by the greater degree of vertical integration in Germany of airport activities, as for example the handling is managed by the airport operator itself in this country. Finally, Marques and Barros (2010) find that public airports are less efficient that privately owned airports.

It should be noted that privatization can have an indirect impact to the extent that usually accompanied by new mechanisms of regulation of prices (Bel \& Fageda, 2012). In this regard, Neimeier (2009) suggests the need of a regulatory reform of large airports to provide more incentives for cost savings and efficient pricing and investment.

Table 1 shows the airport operators in the sample that have been either fully or partially privatized. The privatization of the BAA in 1987 was the first such experience in Europe. At the time of its privatization, the firm was managing three airports in the 
London area (Heathrow, Gatwick and Stansted), three airports in Scotland (Aberdeen, Edinburgh, Glasgow) and Southampton. Since the early nineties, many other airport operators have been privatized in the UK. In fact, Manchester airport is currently the only large British airport managed by a government-owned enterprise. Note that airport privatization in the United Kingdom has generally been more prevalent than in the rest of Europe, and it has been of a different nature. Private investors in the UK have taken on the management of British airports, and at the same time they have purchased the airport infrastructure and land (with few exceptions, prominent among which is Luton Airport). Thus, airport privatization in the UK typically involves the transfer of assets to private investors.

\section{$<<$ Insert Table 1 about here $>>$}

By contrast, in continental Europe, airport privatization typically means that private investors gain control of the firm managing the airport through a long-term concession, but the government retains ownership of the infrastructure and land. Hence, in continental Europe privatization is usually implemented through the contracting out of airport management.

It is clear, therefore, that the airport privatization program has been particularly ambitious in the UK, involving full privatization in most cases. However, several large airports have also been privatized in Italy and Germany. The privatization of Venice airport took place at the same time as that of the BAA. In the middle of the nineties, the operators at Fiumicino and Ciampino in Rome and at the airport in Naples were sold to private investors. More recently, the airports of Pisa, Torino and Bologna have been fully or partially privatized. In Germany, private investors are shareholders of three of the country's largest airports - Frankfurt, Dusseldorf and Hamburg - and a number of 
others including Hanover. Finally, several airports in Europe's capital cities have been fully or partially privatized since the mid-nineties. These include Charles de Gaulle and Orly in Paris, Athens, Budapest, Brussels, Copenhagen and Vienna.

When private investors are not key shareholders in the firm managing the airport, regional or local governments are typically in charge of individual airports. However, there are a number of exceptions to this pattern; for example, the central government manages the airports of Amsterdam, Dublin and Prague. In each case, though, there were plans to privatize, but they have yet to be implemented. In addition, a number of central governments manage airports as a single national system. This is the case for example of Spain, Portugal, Finland, Norway or Romania (and to a lesser extent, Sweden as well). All these countries, with the exception of Spain, are characterized by the heavy concentration of air traffic in the capital city.

\section{EMPIRICAL MODEL}

In this section, we estimate an equation that considers factors explaining privatization of European airports. There is an extensive empirical literature that examines factors explaining privatization. ${ }^{5}$ As far as we know, this is the first multivariate empirical study that focuses on airports.

Previous studies that put the attention on specific services use as dependent variable a dichotomous variable that takes the value one when the service has been privatized and zero in other cases. However, government choices may lie in a middle way between pure private and pure public production. Indeed, it is quite usual in some services like airports to find a partial privatization where the government retains a majority or minority share in the capital of the firm. To take this into account, we use as

\footnotetext{
${ }^{5}$ See Bel \& Fageda (2007b) and Bel, Fageda (2009) for a statistical review of this literature.
} 
dependent variable the percentage of private ownership of the firm that manages the airport. In Europe, all airports with a significant level of traffic are managed by firms subject to commercial laws rather than by administrative entities. However, the percentage of shares of these firms controlled by private investors or governments is quite diverse across different countries.

As determinants of privatization, we must take into account variables that may influence on the interest of private investors and variables that may provide incentives to governments to privatize. In this regard, most of previous studies on factors explaining privatization use variables for fiscal stress and ideology as explanatory factors. Furthermore, some of the variables used previously are specific of the considered service. Here, we use variables that account to fiscal stress and ideology of the government and specific variables related to the airports of the sample; size, type of airlines operating there and competition. We also include country specific variables to capture differences in the national policies of European countries.

The empirical analysis is applied to European airports that generate a high volume of traffic: the sample comprises the 100 airports in the European Union, Switzerland and Norway with most passenger traffic in 2007. It is a fairly homogeneous area in economic terms and it is an area for which the information required for a study of this nature is available.

We estimate the following equation for factors explaining the privatization of airport $a$ in country $c$ :

Private $_{a c}=\alpha+\beta_{1}$ Total_Traffic $a c+\beta_{2}$ Number_nearby_airports ${ }_{a c}+$ $\beta_{3} \%$ Airline_alliance_traffic ${ }_{a c}+\beta_{4} D_{a \mathrm{c}}^{\text {slots }}+\beta_{5}$ PublicDebt ${ }_{\mathrm{c}}+\beta_{6}$ Ideology $_{c}+\beta_{7} \mathrm{D}^{\mathrm{system}}{ }_{c}+$ $\beta_{8} D^{U K}{ }_{c}+\varepsilon$ 
where the variable to be determined is the percentage of private property owned by the management company. We gathered information about the ownership structure of the management companies at all the airports. The sources of information regarding ownership were the web pages of the airports and the civil aviation authorities and the following studies: Oum et al. (2004), Marques and Brochado (2008) and Gillen and Niemeier (2008). The explanatory variables in equation (1) are:

1) The airport's total volume of traffic, Total_Traffic. Total traffic data up to 2007 are available on the Eurostat web page. We expect a positive sign in the coefficient associated to this variable. Private investors may have more interest in larger airport because the expectations of future profits are higher. Furthermore, governments may obtain more revenues from the sale of a larger airport.

2) The number of airports that lie fewer than $100 \mathrm{~km}$ from airport $a$, and which are managed by different operators, Number_nearby_airports. We only consider airports with passenger traffic greater than 150,000 individuals. This traffic threshold is the same as that used by Eurostat for differentiating between main and small commercial airports.

We expect a negative sign in the coefficient associated to this variable. Private investors may be less interested in airports subject to competition from nearby facilities because such competition will push profits downward. From the point of view of governments, it is not clear whether they will have more incentives to privatize airports subject to competition.

3) The percentage of traffic channeled by the airlines integrated within intercontinental airline alliances; Oneworld, Star Alliance and SkyTeam, \%Airline_alliance_traffic. In this regard, we can distinguish between two types of business models in the current aviation market. First, network airlines that are integrated 
in global alliances and that exploit the connecting traffic through hub-and-spoke systems. Second, low-cost airlines that are especially competitive in point-to-point short haul routes. Market share data for the airlines that operate at the respective airports for 2007 are taken from information supplied by the Official Airlines Guide (OAG).

Airports where a high proportion of traffic is channeled by network airlines may work as a hub for one of these airlines. ${ }^{6}$ Given the levels of traffic, governments could retain a majority share even when they choose to private them because hub airports may have a strategic role for national economic policies. Once we control for traffic, it is not clear a priori whether private investors will have more interest in airports dominated by network airlines.

4) Government (central, regional and local) consolidated gross debt as a percentage of GDP in 2007, PublicDebt.

We expect a positive sign in the coefficient associated to this variable. Indeed, governments may have strong incentives to privatize airports when they are subject to financial constraints. Governments may obtain substantial revenues from the sale of airports even in the case they retain some shares of the firm. ${ }^{7}$ Furthermore, investments to improve and expand current capacity of airports are frequently needed and governments may use privatization to save resources to that end.

\footnotetext{
$6 \%$ Airline_alliance_traffic has been shown to be the most important factor determining the degree of hub characteristics in each airport, especially when considering the largest airports, as we do in our sample. Furthermore, our variable is almost perfectly negatively correlated with \%of low carriers in airports (Fageda and Flores-Fillol, 2012). Therefore, considering simultaneously our variable and a variable for $\%$ of low costs is not necessary, and would undermine the robustness of our estimation.

${ }^{7}$ We are thankful to a referee for the advice to use a variable related to non-aeronautical revenues in each airport. Indeed, that could be an interesting variable to include in the estimation, but our sample will have a considerable reduction because of lack of homogeneous data for many airports.
} 
5) An index of the ideological orientation of the political party in the central government, Ideology. We use the index built by the World Bank concerning the party orientation with respect to economic policy using the following criteria. Right: for parties that are defined as conservative, Christian democratic, or right-wing. Left: for parties that are defined as communist, socialist, social democratic, or left-wing. Center: for parties that are defined as centrist or when party position can best be described as centrist (e.g. party advocates strengthening private enterprise in a social-liberal context). This index variable takes the value 1 for right wing parties, the value 2 for centrist parties and the value 3 for left wing parties. Data of this variable refer to the first year of privatization, while we refer to 2007 when the airport has not been privatized.

We expect a negative sign in the coefficient associated to this variable. A priori right-wing parties should be more favorable to private production, while left-wing parties should be more favorable to maintain public firms.

6) Dummy variable for coordinated airports in the allocation of slots, $D^{\text {slots }}$. It takes the value one for coordinated airports and the value zero for non-coordinated airports and schedule-supervised airports. The International Air Transport Association (IATA) classifies airports according to the degree of excess demand when establishing the procedures for allocating slots. The degree of excess of demand should be higher in coordinated airports. This variable is the most accurate indicator of the levels of congestion that we have been able to use.

The expected sign of the coefficient associated to this variable is a priori ambiguous. It is not clear neither the interest of governments nor private investors on engaging in the privatization of congested airports. Current profitability levels of congested airports may be high because of the intense utilization of the capacity. However, the amount of future investments needed to maintain the service levels may also be relevant. Given the 
indivisibilities that characterize the airport industry, current profit levels may be combined with future losses.

One could argue that congested airports require investments to expand capacity and therefore they might need private funds. However, this does not mean that congested airports are more likely to be private or public in a specific year. It could push future plans of privatization. As we only have data for one year, we must recognize that a possible limitation of our analysis is that we are not able to capture the dynamics of privatization policies in the airport industry.

7) A dummy variable for airports located in United Kingdom, $D^{U K}$. We expect a positive sign in the coefficient associated to this variable. Given the value of the other variables, United Kingdom has traditionally shown a stronger bias towards private ownership than countries in continental Europe.

8) A dummy variable for airports in countries that are managed by a single entity as a system, $D^{\text {system }}$. These countries are Spain, Portugal, Greece (except Athens), Norway, Poland, Romania, Ireland and Finland. Some countries like Poland or Ireland have undertaken some reforms towards an individual management but most of airports are still controlled by the central government.

We expect a negative sign in the coefficient associated to this variable. Privatization of airports managed like a system is more complicated than the sale of individual firms. Within the context of individualized management, privatization (full or partial) just implies the sale (all or some) shares of the public firm that manages the airport to private investors. Under a centralized management model, government must implement a restructuring process towards individual management prior to privatization. Otherwise, the public monopoly would be replaced by a private monopoly with the logical concerns for users (airlines, passengers). Furthermore, privatization of all 
airports as a block would imply that non-profitable airports are also included in the sale. ${ }^{8}$

Table 2 shows the descriptive statistics of the variables used in the empirical analysis, while table 3 shows the correlation matrix.

$$
\begin{aligned}
& <<\text { Insert Table } 2 \text { about here }>> \\
& <<\text { Insert Table } 3 \text { about here }>>
\end{aligned}
$$

The dependent variable takes a value within the range $0-1$ so that a standard Ordinary Least Square regression is not applicable. We use two different techniques to estimate the equation for the determinants of (partial) privatization. First, we use the generalized linear model with fractional response variables that should be used when the variable of interest is a proportion or a fraction. Recall that our dependent variable is the percentage of private property owned by the management company. ${ }^{9}$

Second, our dependent variable may have an over-representation of observations with value zero (pure public production). Hence, we also use a complementary log-log model where the dependent variable is a binary variable that takes the value one when there is some degree of private production and zero in case of pure public production. The complementary log-log analysis is an alternative to the standard discrete choice

\footnotetext{
${ }^{8}$ This fact could be compensated if the acquiring companies are granted monopolistic power over all the airport system, because monopolistic conditions could entail larger future benefits so a higher upfront payment in privatization. However, as shown by recent activity by the UK Competition Commission forcing divestiture of several BAA airports because of market dominance, regulatory risks of transferring a monopoly to private partners in the sector is high, which could be a deterrent for likely private partners in this type of operation, as shown for example by the long experience of failed privatization attempts in Spain, the country with the largest integrated management system in the OECD.

${ }^{9}$ See Papke and Wooldridge (1996) for details of this econometric method.
} 
models, but it is unlike these models in that the distribution of the dependent variable is not symmetric about 0 . Typically this model is used when the positive outcome is rare.

In both regressions, standard errors are robust to any problem of heterocedasticity and are clustered at the country level to take into account the possible correlation of airports from a same country.

Table 4 depicts the results of the estimation of equation (1) with the two different techniques. Results are qualitatively identical for all explanatory variables except the one for the percentage of traffic channeled by the airlines integrated within intercontinental airline alliances. The coefficient associated with this variable is only statistically significant in the regression that uses the fractional response variables method.

\section{$<<$ Insert Table 4 about here $>>$}

All the variables have the expected signs and are statistically significant, with the exception of the variable related to the ideology of the political party in the year of the first sale which is not statistically significant.

First of all, we find that airport privatization seems to be a pragmatic choice of governments. The variable of ideology is not statistically significant, while variables related with the economic interests of private investors or governments are clearly statistically significant.

Indeed, larger airports are more likely to be have a higher degree of private involvement because we find that the coefficient associated to the variable of traffic is positive and statistically significant. On the contrary, airports subject to competition from nearby facilities are less likely to be privatized because the coefficient associated to the variable of number of nearby airports is negative and statistically significant. 
Thus, governments may have more incentives to sale some (or all) shares of airports with stronger expectations of future profits, because private investors may be willing to spend more resources to get involved in those airport managing firms.

Given the levels of traffic, private investors may be less interested in congested airports because they must afford future investments in improving and expanding current capacity. In this regard, the coefficient associated to the variable of congestion (dummy for slot-coordinated airports) is negative and statistically. Note also that airports with a higher proportion of traffic channeled by alliances are less likely to be privatized. ${ }^{10}$ Airports that are used by network airlines as a hub may be considered a strategic asset for governments.

From the government point of view, it is more likely that airports are privatized in countries where the amount of public debt is higher. The coefficient associated to the variable of public debt is positive and statistically significant. This is consistent with previous literature on factors explaining privatization in which a typical result is that fiscal stress is a relevant explanatory factor of government service delivery choices, particularly in services involving important investments needs. Moreover, we must recall that full or partial privatization of airports can be used by government as a tool for obtaining revenues, given the high degree of commercialization of these facilities.

Furthermore, we find that the share of private investors in airport managing firms is higher in the United Kingdom than in countries of continental Europe. The coefficient associated to the dummy variable for United Kingdom is positive and statistically significant. In this regard, note that full privatization is typical in the United Kingdom while partial privatization (where the government retains some shares of the firm) is more usual in continental Europe. Finally, we find clear evidence that privatization is

\footnotetext{
${ }^{10}$ Recall that this variable is only statistically significant in the equation that uses the fractional response variables method.
} 
less likely in airports managed like a system because the dummy variable for these countries is negative and statistically significant.

\section{CONCLUSIONS}

Mixed public-private companies have emerged in several sectors, such as local public services and transport infrastructure, as delivery forms that escape the dilemma between pure public and pure private forms. While mixed public-private companies are present in several continental European countries (as well as in other regions of the World, like Latin America), Anglo-Saxon types of legal regulations do not easily provide a framework prone to sharing government and private ownership within the same organization. Probably because of this, study of partial privatization and mixed publicprivate companies in public services is very scant.

In this paper we undertake an empirical study that allows us to analyze the factors explaining mixed delivery choices, and also the degree of private participation in the partially privatized firms, an analysis that has been so far absent in the literature.

We find that the degree of privatization of airports seems to be a pragmatic choice of governments. The variable of ideology is not statistically significant, while variables related with the economic interests of private investors or governments are clearly positive and statistically significant. Indeed, airports with stronger expectations of future profits are more likely to undergo more intense privatization. This is the case of larger airports and those not subject to competition from nearby facilities.

Furthermore, we find that it is more likely that airports have higher degree of privatization in countries where the amount of public debt is higher. On the contrary, airports that may be considered as strategic for governments, (i.e.; airports that are used by network airlines as a hub) are less likely to be privatized. 
We also confirm that the share of private investors in airport managing firms is higher in the United Kingdom than in countries of continental Europe. In this regard, note that full privatization is typical in the United Kingdom while partial privatization (where the government retains some shares of the firm) is the most frequent form of privatization in continental Europe. Finally, we find clear evidence that privatization is less likely in airports managed like a system.

In all, we find that Countries in the European Union other than the UK have chosen a strategy of using mixed public-private companies to give room to private interests in airport management. The fact that airports - particularly largest ones- are seen as strategic facilities, which retain some characteristics of local/regional monopoly, likely explains the small frequency of full privatization -not only of assets, but also of management- in Continental Europe. Within this framework, mixed public-private companies can offer a viable alternative for cooperation between public and private interests. Whether this is a good strategy regarding costs is largely an unexplored issue, with should receive more attention in future research. 


\section{REFERENCES}

Agranoff, R. and M. McGuire. 2003. Collaborative Public Management: New Strategies for Local Governments. Washington, DC: Georgetown University Press

Albalate, D., G. Bel and R. Geddes. 2011. On the determinants of PPPs contractual choice in the United States. Working Paper.

Albalate, D., G. Bel and R. Geddes. 2012. "Recovery risk and labor costs in publicprivate partnerships: Contractual choice in the US water industry." Local Government Studies, forthcoming.

Backx, M., M. Carney and E. Gedajlovic. 2002. "Public, private and mixed ownership modes and the performance of international airlines." Journal of Air Transport and Management, 8(4): 213-220.

Bel, G. 2006. Economía y política de la privatización local. Madrid: Marcial Pons.Bel, G. and X. Fageda. 2007a. "Airport Management and Airline Competition in OECD Countries.” Pp 85-105 F. Fichert, J. Haucap and K. Rommel (eds.), Competition Policy in Network Industries, Berlin: Lit Verlag.

Bel, G. and X. Fageda. 2007b. "Why do local governments privatize public services? A survey of empirical studies." Local Government Studies 33(4): 517-534.

Bel, G. and X. Fageda. 2009. "Factors explaining local privatization: a meta-regression analysis." Public Choice 139(1/2): 105-119.

Bel, G. and X. Fageda. 2010. "Partial privatization in local services delivery: An empirical analysis on the choice of mixed firms." Local Government Studies 36(1): 129-149

Bel, G. and X. Fageda. 2012. Market power, competition and post-privatization regulation: Evidence from changes in regulatory design of European airports, Working paper.

Bickers, K.N., S. Post and R.M. Stein. 2010. "The Political Market for Intergovernmental Cooperation.” Pp 161-175 R.C. Feiock and J.T. Scholtz, eds., Self-organizing federalism: Collaborative mechanisms to mitigate institutional collective action. Cambridge: Cambridge University Press.

Bognetti, G. and L. Robotti. 2003. "The reform of local public utilities in Italy." Annals of Public and Cooperative Economics 74(1): 117-137.

Bognetti, G. and L. Robotti. 2007. "The provision of local public services through mixed enterprises: The Italian case." Annals of Public and Cooperative Economics 78(3): 415-437.

Brown, T. L. and M. Potoski. 2003a. "Transaction costs and institutional explanations for government service production decisions." Journal of Public Administration Research and Theory 13 (4): 441-468.

Brown, T. L. and M. Potoski. 2003b. "Managing contract performance: A transaction cost approach." Journal of Policy Analysis and Management 22 (2): 275-297.

Brown, T. L. and M. Potoski. 2005. "Transaction Costs and Contracting: The Practitioner Perspective." Public Performance and Management Review 28(3): 326-351.

Carney, M. and K. Mew. 2003. "Airport governance reform: a strategic management perspective." Journal of Air Transport Management 9(4): 221-232

Carr, J.B., K. LeRoux, and M. Shrestha. 2009. "Institutional Ties, Transaction Costs, and External Service Production." Urban Affairs Review 44(3): 403-27.

Davis, Mark W. 2012. Fragmentation Versus Consolidation: Investigating Efficiency and equity in Solid Waste Collection at the City Level in the Cities of Colorado Springs, Denver, and Indianapolis. Paper presented at the 2012 American Political Science Association Annual Meeting 
Engel, E., R. Fischer and A. Galetovic,. Forthcoming. The Economics of Public-Private Partnerships: A Basic Guide. Cambridge University Press, forthcoming

Engel, E., R. Fischer and A. Galetovic. Forthcoming b. "The Basic Public Finance of Public-Private Partnerships." Journal. of the European Economic Association, forthcoming http://www.eeassoc.org/doc/upload/Engel-etal20110411185255.pdf

Estache, A. 2006. "PPI divorces vs. PPI partnerships in Infrastructure." Review ofIndustrial Organization 29 (1), 3-26

Fageda, X. And R. Flores-Fillol, 2012. "On the optimal distribution of traffic of network airlines.”. European Economic Review, 56(6): 1164-1179. Feiock, R.C., 2007. "Rational Choice and Regional Governance." Journal of Urban Affairs 29(1): 47-63.

Feiock, R.C., and J.T. Scholz, eds. 2010. Self-organizing federalism: Collaborative mechanisms to mitigate institutional collective action. Cambridge: Cambridge University Press.

Freestone, R. and D. Baker. 2010. "Challenges in land use planning around Australian airports". Journal of Air Transport Management 16(5): 264-271.

Gillen, D. and H.-M. Niemeier. 2008. "The European Union: Evolution of Privatization, Regulation, and Slot Reform." Pp 36-63 C. Winston and G. de Rus (eds.), Aviation Infrastructure Performance. A Study in Comparative Political Economy. Washington DC: Brookings Institution Press.

Hefetz, A. and M. E. Warner. 2012. "Contracting or Public Delivery? The importance of service, market and management characteristics". Journal of Public Administration Research and Theory 22(2): 289-317.

Holzer, M. And J. Fry. 2011. Shared services and municipal consolidation. A critical analysis. Alexandria (VA): Public Technology Institute.

Krueger, S. and E.M. Bernick. 2010. "State Rules and Local Governance Choices." Publius. The Journal of Federalism 40 (4): 697-718

Kwon, S-W. and R.C. Feiock. 2010. "Overcoming the Barriers to Cooperation: Intergovernmental Service Agreements.” Public Administration Review 70(6): 876-884

LeRoux, K., P. W. Brandenburger, and S. K. Pandey. 2010. "Interlocal Service Cooperation in US Cities: A Social Network Explanation." Public Administration Review 70(2): 268-278.

LeRoux, K. and J. B. Carr. 2007. "Explaining Local Government Cooperation on Public Works: Evidence from Michigan." Public Works Management and Policy 12(1): 344-58.

Marques, R.C. and C.P. Barros. 2010. "Performance of European airports: regulation, ownership and managerial efficiency." Applied Economics Letters 18(1): 29-37.

Marques, R. C. and A. Brochado. 2008. "Airport regulation in Europe: Is there need for a European observatory?." Transport Policy 15(3): 163-172.

Matsumura, T. 1998. "Partial privatization in mixed duopoly." Journal of Public Economics 70(3): 473-483

Matsumura, T. and O. Kanda. 2005. "Mixed Oligopoly at Free Entry Markets." Journal of Economics 84(1): 27-48.

Miranda, R. and A. Lerner. 1995. "Bureaucracy, Organizational Redundancy and the Privatization of Public Services." Public Administration Review 55(2): 193-200.

Müller, J., T. Ülkü, and J. Zivanovic. 2008. Privatization, restructuring and its effects on performance: A comparison between German and British airports. German Airport Performance, mimeo. 
Niemeier, H-M. 2009. Regulation of Large Airports: Status Quo and Options for Reform. International Transport Forum, OECD. Discussion paper num. 2009-10

Oum, T.H, N. Adler and C. Yu. 2006. "Privatization, corporatization, ownership forms and their effects on the performance of the world's major airports." Journal of Air Transport Management 12 (3): 109-121.

Oum, T.H., J. Yan, and C. Yu. 2008. "Ownership forms matter for airport efficiency: A stochastic frontier investigation of worldwide airports." Journal of Urban Economics 64(3): 422-435.

Papke, L. and J. Wooldridge. 1996. "Econometric methods for fractional response variables with an application to $401(\mathrm{k})$ plan participation rates." Journal of Applied Econometrics 11(6): 619-632.

Parker, D. 1999. "The performance of BAA before and after privatization." Journal of Transport Economics and Policy 33 (2): 133-145.

Perry, J.L. and H.G. Rainey. 1988. "The Public-Private Distinction in Organization Theory: A Critique and Research Strategy." Academy of Management Review, 13(2): 182-201.

Schmitz, P. W. 2000. "Partial privatisation and incomplete contracts; the proper scope of government reconsidered." Finanzarchiv, 56(4): 394-411.

Shrestha, M. K. and R. C. Feiock.http://prq.sagepub.com/content/64/3/573.abstract - aff-1 2011. "Transaction Cost, Exchange Embeddedness, and Interlocal Cooperation in Local Public Goods." Political Research Quarterly 64 (3): 573-587.

Sonenblum, S., J.J. Kirlin and J.C. Reis 1977. How Cities Provide Services. Cambridge, (MA): Ballinger.

Stein, R.M. 1990. Urban Alternatives. Public and Private Markets in the Provision of Local Services. Pittsburgh (PA): University of Pittsburgh Press.

Stiglitz, J.E. 1989. The Economic Role of the State. Oxford: Basil Blackwell.

Warner, M. E. and G. Bel. 2008. "Competition or Monopoly? Comparing Privatization of Local Public Services in the U.S. and Spain." Public Administration 86 (3): 723-735.

Warner, M. E. and R. Hebdon. 2001. "Local government restructuring: privatization and its alternatives." Journal of Policy Analysis and Management 20(2): 315-336.

Warner, M. E. and A. Hefetz. 2008. "Managing Markets for Public Service: The Role of Mixed Public/Private Delivery of City Services". Public Administration Review 68(1): 155-166.

Wood, Curtis. 2006. "Scope and Patterns of Metropolitan Governance in Urban America: Probing the Complexities in the Kansas City Region." American Review of Public Administration 36(3): 337-353. 
TABLES

Table 1. Privatization of main airports in Europe

\begin{tabular}{|c|c|c|}
\hline Airport & \% Private ownership & $\begin{array}{c}\text { Year (s) of first sale to private } \\
\text { investors }\end{array}$ \\
\hline London-Heathrow (LHR) & 100 & 1987 \\
\hline London-Gatwick (LGW) & 100 & 1987 \\
\hline London-Stansted (STN) & 100 & 1987 \\
\hline Edinburgh (EDI) & 100 & 1987 \\
\hline Glasgow (GLA) & 100 & 1987 \\
\hline Aberdeen (ABZ) & 100 & 1987 \\
\hline Venice (VCE) & 71 & 1987 \\
\hline Liverpool (LPL) & 76 & 1990 \\
\hline Glasgow-Prestwick (PIK) & 100 & 1992 \\
\hline Vienna (VIE) & 60 & 1992-1995-2001 \\
\hline Copenhagen $(\mathrm{CPH})$ & 60.8 & 1994-1996-2000 \\
\hline Belfast (BFS) & 100 & 1994 \\
\hline London city (LCY) & 100 & 1995 \\
\hline Birmingham (BHX) & 51 & 1997 \\
\hline Bristol (BRS) & 100 & 1997 \\
\hline Naples (NAP) & 70 & 1997 \\
\hline Hahn (HHN) & 65 & 1997 \\
\hline Rome-Fiumicino (FCO) & 95.75 & $1997-2001$ \\
\hline Rome-Ciampino (CIA) & 95.75 & 1997-2001 \\
\hline London-Luton (LTN) & 100 & 1998 \\
\hline Dusseldorf (DUS) & 50 & 1998 \\
\hline Hannover (HAJ) & 30 & 1998 \\
\hline Zurich (ZRH) & 42 & 2000 \\
\hline Hamburg (HAM) & 49 & 2000 \\
\hline Torino (TRN) & 44.29 & 2000 \\
\hline Frankfurt (FRA) & 29 & 2001 \\
\hline Athens (ATH) & 45 & 2001 \\
\hline Newcastle (NCL) & 49 & 2001 \\
\hline Malta (MLA) & 80 & $2002-2005$ \\
\hline Brussels (BRU) & 62.1 & 2005 \\
\hline Budapest (BUD) & 75 & 2005 \\
\hline Larnaca (LCA) & 100 & 2005 \\
\hline $\begin{array}{l}\text { Pisa (PSA) } \\
\end{array}$ & 78 & 2005 \\
\hline Paris-Charles de Gaulle (CDG) & 32.5 & 2006 \\
\hline Paris-Orly (ORY) & 32.5 & 2006 \\
\hline Bolonia (BLQ) & 13.90 & 2007 \\
\hline Leeds (LBA) & 100 & 2007 \\
\hline
\end{tabular}

Note: We do not account for further changes in the identity of private investors after the first sale.

Source: Gillen and Niemeier (2008), Graham (2006) and web sites of the corresponding airports. 
Table 2. Descriptive statistics of the variables used in the empirical analysis

\begin{tabular}{|c|c|c|c|c|}
\hline Variable & Mean & $\begin{array}{c}\text { Standard } \\
\text { deviation }\end{array}$ & $\begin{array}{c}\text { Minimum } \\
\text { value }\end{array}$ & $\begin{array}{c}\text { Maximum } \\
\text { value }\end{array}$ \\
\hline Private (\% private owership) & 0.26 & 0.38 & 0 & 1 \\
\hline Total traffic (000 passengers) & 11648.15 & 12937.78 & 2420.71 & 68279.36 \\
\hline Number_nearby airports & 0.67 & 1.005 & 0 & 5 \\
\hline \%Traffic_airlines_alliances & 0.43 & 0.28 & 0 & 0.90 \\
\hline $\begin{array}{c}\mathrm{D}^{\text {Slots }}(1=\text { airports coordinated } \\
\text { slots) }\end{array}$ & 0.6 & 0.49 & 0 & 1 \\
\hline PublicDebt (\% over GDP) & 57.71 & 26.06 & 9 & 107.4 \\
\hline $\begin{array}{c}\text { Ideology (index of the political } \\
\text { party in the government; right } \\
(1), \text { Center (2), left (3) }\end{array}$ & 2.22 & 0.93 & 1 & 3 \\
\hline $\begin{array}{c}\mathrm{D}^{\mathrm{UK}}(1=\text { Airports located in } \\
\text { United Kingdom) }\end{array}$ & 0.17 & 0.37 & 0 & 1 \\
\hline $\begin{array}{c}\mathrm{D}_{\text {System }}(1=\text { Airports located in } \\
\text { countries with an integrated } \\
\text { system) }\end{array}$ & 0.35 & 0.49 & 0 & 1 \\
\hline
\end{tabular}

Table 3. Matrix of correlations of the variables used in the empirical analysis

\begin{tabular}{|c|c|c|c|c|c|c|c|c|c|}
\hline & Private & Traffic & Nearby & alliances & slots & debt & ideology & UK & System \\
\hline Private & 1 & & & & & & & & \\
\hline Traffic & 0.11 & 1 & & & & & & & \\
\hline Nearby & 0.36 & 0.03 & 1 & & & & & & \\
\hline alliances & -0.18 & 0.42 & -0.20 & 1 & & & & & \\
\hline slots & -0.30 & 0.38 & -0.28 & 0.17 & 1 & & & & \\
\hline debt & 0.05 & -0.08 & 0.01 & 0.12 & & 1 & & & \\
\hline ideology & -0.24 & -0.04 & -0.20 & 0.32 & 0.32 & 0.03 & 1 & & \\
\hline UK & 0.65 & 0.06 & 0.54 & -0.33 & -0.33 & -0.23 & -0.20 & 1 & \\
\hline System & -0.47 & -0.12 & -0.41 & -0.07 & 0.26 & -0.30 & 0.40 & -0.33 & 1 \\
\hline
\end{tabular}

Table 4. Estimates of the equation for factors explaining partial privatization

\begin{tabular}{|c|c|c|}
\hline & \multicolumn{2}{|c|}{ Dependent variable } \\
\hline Explanatory variables & $\begin{array}{l}\text { Share Private Ownership } \\
\text { (Generalized linear model with } \\
\text { fractional response variables) }\end{array}$ & $\begin{array}{l}\text { Dummy variable. 0:pure public production, } \\
\text { 1: some degree of private production } \\
\text { (Complementary log-log model) }\end{array}$ \\
\hline Total_Traffic & $0.00005(0.00001)^{* * *}$ & $0.00005(0.00002)^{* * *}$ \\
\hline Number_nearby_airports & $-0.42(0.24)^{*}$ & $-0.26(0.11)^{* *}$ \\
\hline \%Traffic_airlines_alliances & $-1.78(0.94)^{* *}$ & $-0.086(0.95)$ \\
\hline $\mathbf{D}^{\text {slots }}$ & $-1.22(0.49)^{* * *}$ & $-1.12(0.45)^{* *}$ \\
\hline PublicDebt & $0.026(0.013)^{* *}$ & $0.035(0.015)^{* *}$ \\
\hline Ideology & $-0.13(0.39)$ & $0.012(0.003)$ \\
\hline$D^{\mathrm{UK}}$ & $3.14(0.52)^{* * *}$ & $2.28(0.71)^{* * *}$ \\
\hline $\mathbf{D}^{\text {System }}$ & $-3.08(0.57)^{* * *}$ & $-2.54(0.66)^{* * *}$ \\
\hline Intercept & $-1.72(0.87)^{* *}$ & $-2.86(0.9)^{* * *}$ \\
\hline $\mathbf{N}$ & 100 & 100 \\
\hline Log-pseudolikelihood & -29.38 & -36.28 \\
\hline
\end{tabular}

